\title{
Protein profile of lambs experimentally infected with Haemonchus contortus and supplemented with selenium and copper
}

\author{
Guilherme Costa Fausto ${ }^{1}$, Felipe Lamberti Pivoto', Márcio Machado Costa², Sônia Terezinha dos Anjos Lopes², \\ Raqueli Teresinha França ${ }^{2}$, Marcelo Beltrão Molento ${ }^{3}$, Antonio Humberto Hamad Minervino ${ }^{4}$, \\ João Batista Teixeira da Rocha ${ }^{5}$ and Marta Lizandra do Rêgo Leal ${ }^{1^{*}}$
}

\begin{abstract}
Background: Gastrointestinal nematodes cause significant economic losses in the sheep industry, with frequent reports of anthelmintic resistance. Therefore, alternative methods to control these parasites are necessary. Thus, the aim of the present study was to assess the effect of treatment with selenium and copper on the protein profile of sheep that were experimentally infected with Haemonchus contortus.

Methods: Twenty-eight lambs were experimentally infected with $H$. contortus and divided into four experimental groups as follow: G1 - untreated animals; G2 - treated with sodium selenite; G3 - treated with copper; G4 - treated with sodium selenite and copper. The serum protein, body weight and egg count per gram of feces (EPG) were assessed at the baseline and after 20, 40,60 and 80 days. The parasite burden was assessed 80 days after the beginning of the experiment.

Results: Higher levels of total protein and gamma globulin were observed in the lambs treated with sodium selenite and copper on D80. Copper acted as a growth promoter. The copper-supplemented groups exhibited higher daily and total weight gain. The association of selenium and copper altered the protein profile of sheep. Copper and selenium supplementation reduced EPG and worm burden at the end of the experiment. To the best of our knowledge, this is the first study to demonstrate the positive effect of the combined parenteral supplementation of Se and $\mathrm{Cu}$ on $\mathrm{H}$. contortus infection.
\end{abstract}

Conclusions: This injectable supplementation could be used as an auxiliary method to control $H$. contortus in sheep.

\section{Background}

Gastrointestinal nematodes are important parasites in sheep flocks $[1,2]$, which compromise this activity through a marked reduction in weight gain among the animals $[3,4]$. Among gastrointestinal nematodes, Haemonchus contortus is the most prevalent and important parasite of small ruminants $[5,6]$. It is responsible for hematological and biochemical abnormalities such as hypoproteinemia and hypoalbuminemia [7].

\footnotetext{
*Correspondence: martalizandra@gmail.com

'Laboratório de Endocrinologia e Metabologia Animal, Departamento de Clínica de Grandes Animais, Hospital Veterinário Universitário, Universidade Federal de Santa Maria (UFSM), Avenida Roraima 1000, CEP 97105-900 Santa Maria, Rio Grande do Sul, Brasil

Full list of author information is available at the end of the article
}

There have been reports of anthelmintic resistance in gastrointestinal nematodes worldwide $[8,9]$ and the search for alternative methods to control these parasites has become extremely important. Protein supplementation induces an increase of globulin and albumin levels in the animals, with a consequent reduction in egg counts per gram of feces and parasite load $[10,11]$.

One alternative is the use of trace elements, such as selenium, an important element that affects thyroid activity, immune response, defense muscle damage, reproduction, pregnancy and lactation in animals [12]. A number of studies have reported that additional selenium supplementation can increase the globulin and albumin levels in sheep. Copper has also been implicated in 
increased globular volume levels, reduced egg counts per gram of feces and decreased parasite burden in small ruminants [13].

Copper oxide wire particles have the potential to reduce the establishment and worm fecundity of Haemonchus contortus, thereby alleviating the parasite infection by reducing the number of egg-laying nematodes in the abomasum $[14,15]$. According to Burke and Miller [16], multiple doses of copper oxide wire particles were as effective as levamisole in controlling $H$. contortus. On the other hand, Waller et al., [17] concluded that there was little, if any, benefit in copper supplementation to control parasites among Swedish sheep. Burke and Miller [18] reported that dietary CU sulfate failed to control gastrointestinal nematodes in goats. Furthermore, the studies that reported the effectiveness of copper in controlling nematodes used oral supplementation. Therefore, further studies are required to assess the parenteral administration of copper.

Selenium-deficient diets have reduced resistance to helminth infection [17]. Supplementation with selenium has provided greater antioxidant protection against oxidative stress generated by the experimental infection of lambs with $H$. contortus, as well as providing better antioxidant protection for neutrophils $[18,19]$.

Information regarding the parenteral administration of $\mathrm{Cu}$ or Se in sheep infected with $H$. contortus is limited in the literature. As far as we know, there are no existing studies about the possible synergic action of the two trace elements. Thus, our hypothesis is that injectable mineral supplementation of copper and/or selenium will promote an increase of plasma proteins in sheep and may provide a better defense against parasites. The aim of the present study was to assess the effect of selenium and copper on the protein profile, worm burden and weight gain of lambs that were experimentally infected with $H$. contortus.

\section{Methods}

The use of animals in the present study was approved by the Ethics and Animal Experimentation Committee of the Universidade Federal de Santa Maria under protocol number 82/2009.

\section{Animals and diet}

Twenty-eight crossbred Corriedale $\mathrm{x}$ Texel five-month old male lambs were used. The animals were kept in holding pens at the Teaching Veterinary Hospital of the Universidade Federal de Santa Maria (UFSM). Sheep were purchased from a commercial farm in the city of Santa Maria where they were fed only natural pasture and had a history of $H$. contortus infection. There were no reported deaths caused by this parasite.

The animals were submitted to an adaptation period of 40 days when receiving anthelmintic treatment (two doses at an interval of 15 days) with a combination of Closantel and Albendazole $\left(0.75 \mathrm{mg} \mathrm{kg}^{-1}\right.$ and $0.38 \mathrm{mg} \mathrm{kg}^{-1}$, respectively; Closalben ${ }^{\circ}$ Ceva Santé Animale, Paulínia, São Paulo, Brazil). All animals exhibited fecal egg counts of zero after this treatment.

During the adaptation period and throughout the study, sheep were fed at $3.0 \%$ body weight (dry matter basis) with a diet consisting of $30 \%$ oat hay (Avena sativa) and 70\% commercial concentrate (Supra Lã 14, Supra ${ }^{\circ}$, São Leopoldo, Brazil), which were offered three times a day. The diet contained $87.7 \%$ dry matter, $11.6 \%$ crude protein, $22.2 \%$ acid detergent fiber and $1.7 \%$ ether extract. The copper and selenium content in the feed given to the animals were determined at the Chemical Analyses Laboratory of the UFSM. However, due to technical issues, the values were below the detection limits.

\section{Experimental design}

The 28 lambs were stratified into four groups of seven animals each and housed in collective pens (one experimental group per pen). After the adaptation period, all of the animals were experimentally infected with thirdstage infective larvae of $H$. contortus and the groups were established based on the treatment received: G1 - untreated animals; G2 - animals treated with sodium selenite; G3 - animals treated with copper; G4 - animals treated with sodium selenite and copper.

The protein profile, body weight, eggs per gram of feces (EPG) and worm burden of the animals were assessed for 80 days after the beginning of the experimental infection.

\section{Experimental infection}

$H$. contortus larvae, obtained by the O'Sullivan \& Roberts technique [20], were used to infect the animals as described in a previous report [21]. Over a period of 20 days, 500 third-stage infective larvae (L3), in $5 \mathrm{ml}$ of saline, were administered orally to the lambs every second day, totaling 5,000 larvae after 20 days. The first day of infection was designated as day 0 (D0).

\section{Treatment}

The lambs were subjected to intramuscular (IM) treatment with sodium selenite at a dose of $0.2 \mathrm{mg} \mathrm{kg}-1$ (Merck Brazil, Jacarepaguá, RJ, Brazil). The copper (copper lactobionate $5.5 \mathrm{mg} / \mathrm{ml}$, copper gluconate $3.1 \mathrm{mg} / \mathrm{ml}$, and copper octadecanoate $0.98 \mathrm{mg} / \mathrm{ml}$ ) was administered subcutaneously (SC) at a dose of $3.5 \mathrm{mg} \mathrm{kg}^{-1}$ (Cuprhormone ${ }^{\circ}$; Agroinsumos Laboratories, Buenos Aires, Argentina). Sodium selenite supplementation was administered 20 days before D0 and repeated on D0. According to the literature, selenium reaches peak blood level within 60 days of administration [22]. Copper was administered on D0 and 30 days later (D30), since it reaches its sanguine 
peak earlier [23]. This physiological difference in the metabolism of mineral elements was the reason for the different treatment protocols.

\section{Collection and sample analysis}

Blood samples were collected by jugular venipuncture using Vacutainer (Becton, Dickinson and Company, San Jose-CA, USA) on day zero, before the experimental infection (D0), and after 20, 40, 60 and 80 days (D20, D40, D60 and D80, respectively). The sera samples were obtained by centrifugation and stored at $-70^{\circ} \mathrm{C}$ for later analysis. The electrophoretic profile of proteins (total protein, albumin, alpha, beta and gamma globulins) was determined by electrophoresis using cellulose acetate strips [24].

On the days of blood collection, the animals were weighed in the morning after fasting for at least 8 hours. Fecal samples were also collected to quantify the eggs per gram of feces (EPG), using the McMaster technique with a sensitivity of 100 EPG [25]. The parasite load was quantified on D80 according to the classical technique [26], which involved the euthanasia of three animals from each group with $1 \mathrm{~g}$ of thiopental per animal, followed by the administration of $100 \mathrm{ml}$ of potassium chloride.

\section{Statistical analysis}

The protein profile and body weight data were subjected to analysis of variance (ANOVA), followed by Duncan's test for multiple comparisons. The EPG values and the worm burden were subjected to logarithmic transformation $\left(\log _{10} \mathrm{X}+1.5\right)$ and later to the student's t-test, with the significance level set at $5 \%$. The analysis was performed using GraphPad InStat software (GraphPad inc., La Jola, CA, USA).

\section{Results}

Table 1 displays the mean values and the statistical analysis of serum (total protein and albumin). The alpha globulin, beta globulin and gamma globulin results are shown in Table 2. The mean total protein values of G4 were higher $(\mathrm{P}<0.05)$ on $\mathrm{D} 80$ when compared with all other groups. The albumin concentration did not exhibit statistical differences between the groups or the time periods.

This similarity between the serum concentration in the different groups and experimental periods was also observed for alpha globulin and beta globulin. A significant reduction $(\mathrm{p}<0.05)$ was observed in the levels of beta globulin in lambs from G2 and G3, when compared to D0 of the experiment. The levels of gamma globulin in $\mathrm{G} 2$ showed a significant reduction $(\mathrm{p}<0.05)$ on D20, D40, D60 and D80, when compared to D0. On the other hand, gamma globulin levels were significantly higher in G4 $(\mathrm{p}<0.05)$ than in the other groups at the end of the experiment (Table 2).

On D0, sheep from G1, G2, G3 and G4 had an average live weight of $21.50 \mathrm{~kg}, 22.84 \mathrm{~kg}, 23.86 \mathrm{~kg}$ and $25.35 \mathrm{~kg}$, respectively. This difference was due to stratification based on the previous EPG. At the end of the experiment, the total and daily weight gains were higher $(\mathrm{P}<0.05)$ in the copper supplemented groups (Table 3).

On D0, all animals exhibited EPG values equal to zero. These values increased from D20 onwards. At the end of the experiment (D80), lambs from G4 exhibited significantly lower EPG values $(\mathrm{p}<0.05)$, when compared to the other groups (Figure 1). This significant difference was also observed for the mean parasite load, which was 568 in G1, 526 in G2, 430 in G3 and 365 in G4 (Table 3).

\section{Discussion}

$H$. contortus infection in sheep causes disorder in their hematopoietic system, resulting in anemia and severe damage to the abomasal mucosa, including loss of serum proteins [7]. The results of the present study indicated an additive effect of selenium and copper supplementation in lambs from G4, resulting in the reduction of worm burden, which led to less mucosal damage and blood loss, thereby increasing the levels of total protein. This additional action of selenium and copper was clear in the relatively linear relationship of the parasite burden throughout the four groups and by the absence of an increase in serum protein concentration in lambs from

Table 1 - Mean \pm Standard deviation of the serum total protein (TP) and albumin (ALB) in lambs from experimental groups throughout the study

\begin{tabular}{|c|c|c|c|c|c|c|c|c|c|c|}
\hline \multirow[t]{2}{*}{ Groups } & \multicolumn{2}{|l|}{ Do } & \multicolumn{2}{|l|}{ D20 } & \multicolumn{2}{|l|}{ D40 } & \multicolumn{2}{|l|}{ D60 } & \multicolumn{2}{|l|}{ D80 } \\
\hline & $\mathrm{TP}$ & ALB & $\mathrm{TP}$ & ALB & $\mathrm{TP}$ & ALB & TP & ALB & $\mathrm{TP}$ & ALB \\
\hline G1 & $7.98 \pm 0.40^{\mathrm{Aa}}$ & $3.14 \pm 0.36^{\mathrm{Aa}}$ & $7.81 \pm 0.49^{\mathrm{Aab}}$ & $3.30 \pm 0.48^{\mathrm{Aa}}$ & $6.79 \pm 0.95^{\mathrm{Ab}}$ & $3.13 \pm 0.47^{\mathrm{Aa}}$ & $7.30 \pm 0.50^{\text {Aab }}$ & $3.29 \pm 0.66^{\mathrm{Aa}}$ & $6.96 \pm 0.92^{\mathrm{Bab}}$ & $3.12 \pm 0.42^{\mathrm{Aa}}$ \\
\hline $\mathrm{G} 2$ & $8.41 \pm 0.07^{\mathrm{Aa}}$ & $3.49 \pm 0.32^{\mathrm{Aa}}$ & $7.36 \pm 0.41^{\mathrm{ABb}}$ & $3.22 \pm 0.26^{\mathrm{Aa}}$ & $7.05 \pm 0.80^{\mathrm{Ab}}$ & $3.20 \pm 0.34^{\mathrm{Aa}}$ & $6.83 \pm 0.62^{\mathrm{Ab}}$ & $3.11 \pm 0.35^{\mathrm{Aa}}$ & $6.99 \pm 0.88^{\mathrm{Bb}}$ & $3.17 \pm 0.51^{\mathrm{Aa}}$ \\
\hline G3 & $7.80 \pm 0.47^{\mathrm{Aa}}$ & $3.24 \pm 0.23^{\mathrm{Aa}}$ & $6.92 \pm 0.35^{\mathrm{Bb}}$ & $3.04 \pm 0.28^{\mathrm{Aa}}$ & $6.66 \pm 0.59^{\mathrm{Ab}}$ & $2.95 \pm 0.15^{\mathrm{Aa}}$ & $6.67 \pm 0.49^{A b}$ & $2.98 \pm 0.32^{\mathrm{Aa}}$ & $6.62 \pm 0.54^{\mathrm{Bb}}$ & $3.19 \pm 0.40^{\mathrm{Aa}}$ \\
\hline G4 & $7.64 \pm 0.41^{\mathrm{Aa}}$ & $3.18 \pm 0.24^{\mathrm{Aa}}$ & $7.80 \pm 0.58^{\mathrm{Aa}}$ & $3.42 \pm 0.27^{\mathrm{Aa}}$ & $7.25 \pm 0.69^{\mathrm{Aa}}$ & $3.28 \pm 0.37^{\mathrm{Aa}}$ & $7.45 \pm 0.67^{\mathrm{Aa}}$ & $3.38 \pm 0.28^{\mathrm{Aa}}$ & $7.94 \pm 0.76^{\mathrm{Aa}}$ & $3.43 \pm 0.37^{A}$ \\
\hline
\end{tabular}

G1 - infected and untreated animals; G2 - infected and treated with sodium selenite animals; G3 - infected and treated with copper animals; G4 - infected and treated with sodium selenite and copper animals. Different capital letters in the same column indicate a significant difference between the groups ( $p<0.05)$. Different lowercase letters on the same line indicate a significant difference between the experimental periods within a group ( $p<0.05$ ). 
Table 2 - Mean \pm Standard deviation of the serum alpha globulins ( $\alpha$ ), beta globulins $(\beta)$ and gamma globulins $(\mu)$ in lambs from experimental groups throughout the study

\begin{tabular}{|c|c|c|c|c|c|}
\hline Experimental periods & & G1 & G2 & G3 & G4 \\
\hline \multirow[t]{3}{*}{$\overline{\mathrm{DO}}$} & $a$ & $0.89 \pm 0.11^{\mathrm{Aa}}$ & $0.92 \pm 0.15^{\mathrm{Aa}}$ & $0.83 \pm 0.09^{\mathrm{Aa}}$ & $0.82 \pm 0.06^{\mathrm{Aa}}$ \\
\hline & $\beta$ & $0.61 \pm 0.12^{\mathrm{Aa}}$ & $0.59 \pm 0.06^{\mathrm{Aa}}$ & $0.51 \pm 0.07^{\mathrm{Aa}}$ & $0.51 \pm 0.06^{\mathrm{Aa}}$ \\
\hline & Y & $2.54 \pm 0.38^{\mathrm{Aa}}$ & $2.75 \pm 0.35^{\mathrm{Aa}}$ & $2.58 \pm 0.51^{\mathrm{Aa}}$ & $2.45 \pm 0.17^{\mathrm{Aa}}$ \\
\hline \multirow[t]{3}{*}{$\overline{\mathrm{D} 20}$} & $a$ & $0.88 \pm 0.09^{\mathrm{Aa}}$ & $0.81 \pm 0.12^{\mathrm{Aa}}$ & $0.77 \pm 0.09^{\mathrm{Aa}}$ & $0.85 \pm 0.08^{\mathrm{Aa}}$ \\
\hline & $\beta$ & $0.52 \pm 0.08^{\mathrm{Aa}}$ & $0.49 \pm 0.08^{\mathrm{Ab}}$ & $0.45 \pm 0.08^{\mathrm{Aab}}$ & $0.56 \pm 0.13^{\mathrm{Aa}}$ \\
\hline & Y & $2.49 \pm 0.37^{\mathrm{Aa}}$ & $2.29 \pm 00.21^{\mathrm{Ab}}$ & $2.20 \pm 0.25^{\mathrm{Aa}}$ & $2.37 \pm 0.16^{\mathrm{Aa}}$ \\
\hline \multirow[t]{3}{*}{ D40 } & $a$ & $0.73 \pm 0.08^{\mathrm{Aa}}$ & $0.74 \pm 0.09^{\mathrm{Aa}}$ & $0.73 \pm 0.08^{\mathrm{Aa}}$ & $0.74 \pm 0.15^{\mathrm{Aa}}$ \\
\hline & $\beta$ & $0.42 \pm 0.90^{\mathrm{Aa}}$ & $0.42 \pm 0.04^{\mathrm{Ab}}$ & $0.38 \pm 0.07^{\mathrm{Ab}}$ & $0.42 \pm 0.06^{\mathrm{Aa}}$ \\
\hline & $\gamma$ & $2.08 \pm 0.28^{\mathrm{Aa}}$ & $2.17 \pm 0.31^{\mathrm{Ab}}$ & $2.10 \pm 0.39^{\mathrm{Aa}}$ & $2.27 \pm 0.24^{\mathrm{Aa}}$ \\
\hline \multirow[t]{3}{*}{$\overline{\mathrm{D} 60}$} & $a$ & $0.77 \pm 0.07^{\mathrm{Aa}}$ & $0.80 \pm 0.12^{\mathrm{Aa}}$ & $0.71 \pm 0.14^{\mathrm{Aa}}$ & $0.84 \pm 0.16^{\mathrm{Aa}}$ \\
\hline & $\beta$ & $0.51 \pm 0.17^{\mathrm{Aa}}$ & $0.47 \pm 0.06^{\mathrm{Ab}}$ & $0.42 \pm 0.07^{\mathrm{Aab}}$ & $0.47 \pm 0.10^{\mathrm{Aa}}$ \\
\hline & Y & $2.14 \pm 0.22^{\mathrm{Aa}}$ & $1.96 \pm 0.26^{\mathrm{Ab}}$ & $2.04 \pm 0.28^{\mathrm{Aa}}$ & $2.35 \pm 0.43^{\mathrm{Aa}}$ \\
\hline \multirow[t]{3}{*}{ D80 } & $a$ & $0.82 \pm 0.10^{\mathrm{Aa}}$ & $0.88 \pm 0.89^{\mathrm{Aa}}$ & $0.83 \pm 0.13^{\mathrm{Aa}}$ & $0.93 \pm 0.15^{\mathrm{Aa}}$ \\
\hline & $\beta$ & $0.50 \pm 0.16^{\mathrm{Aa}}$ & $0.47 \pm 0.11^{\mathrm{Ab}}$ & $0.38 \pm 0.07^{\mathrm{Ab}}$ & $0.55 \pm 0.14^{\mathrm{Aa}}$ \\
\hline & $\gamma$ & $2.17 \pm 0.37^{\mathrm{Ba}}$ & $2.17 \pm 0.25^{\mathrm{Bb}}$ & $2.15 \pm 0.38^{\mathrm{Ba}}$ & $2.56 \pm 0.31^{\mathrm{Aa}}$ \\
\hline
\end{tabular}

G1 - infected and untreated animals; G2 - infected and treated with sodium selenite animals; G3 - infected and treated with copper animals; G4 - infected and treated with sodium selenite and copper animals. Different capital letters on the same line indicate a significant difference between the groups. Different lowercase letters in the same column indicate a significant difference between the experimental periods within a group ( $p<0.05$ ).

G2 and G3, which only received selenium or copper, respectively.

Kumar et al. [27] observed no changes in the protein profile of uninfected lambs treated with different concentrations of selenium. Dezfoulian et al. [28] found no differences in the red blood cells, hemoglobin and hematocrit of uninfected animals treated with different concentrations of copper. Therefore, the alterations in the protein profile observed in the present study occurred as a result of the parasitic infection and/or the additional effect from both $\mathrm{Cu}$ and $\mathrm{Se}$ on the immune system in response to the infection.

An increase of serum gamma globulin was observed in lambs from G4, which exhibited significantly higher values $(\mathrm{p}<0.05)$ than the other groups on D80, resulting in a reduced EPG (Figure 1) and parasite load (Table 3). These data suggest that supplementation with selenium

Table 3 - Mean \pm Standard deviation of the total and daily weight gain and worm burden of sheep at the end of the experiment (D80)

\begin{tabular}{llll}
\hline Groups & Weight gain $(\mathbf{k g})$ & Daily weight gain $(\mathbf{k g})$ & Worm burden \\
\hline G1 & $4.80^{\mathrm{b}} \pm 1.5$ & $0.060^{\mathrm{b}} \pm 0.019$ & $568^{\mathrm{a}} \pm 707,3$ \\
G2 & $5.23^{\mathrm{b}} \pm 1.5$ & $0.065^{\mathrm{b}} \pm 0.019$ & $527^{\mathrm{a}} \pm 421,9$ \\
G3 & $7.49^{\mathrm{a}} \pm 1.7$ & $0.094^{\mathrm{a}} \pm 0.021$ & $430^{\mathrm{a}} \pm 122,9$ \\
G4 & $7.37^{\mathrm{a}} \pm 0.7$ & $0.092^{\mathrm{a}} \pm 0.008$ & $365^{\mathrm{b}} \pm 117,6$ \\
\hline
\end{tabular}

G1 - infected and untreated animals; G2 - infected and treated with sodium selenite animals; G3 - infected and treated with copper animals; G4 - infected and treated with sodium selenite and copper animals. Different lowercase letters in the same column indicate a significant difference between the groups $(p<0.05)$ and copper increased the levels of protein in the blood and reduced parasitic infection among sheep. An efficient immune response is associated with the levels of selenium in the organism [12]. The supplementation of this mineral may improve both the innate and humoral immune response [29]. Other studies of mineral supplementation, such as one that examined the action of zinc on the productive parameters of sheep [30], have reported increased feed efficiency and body weight among

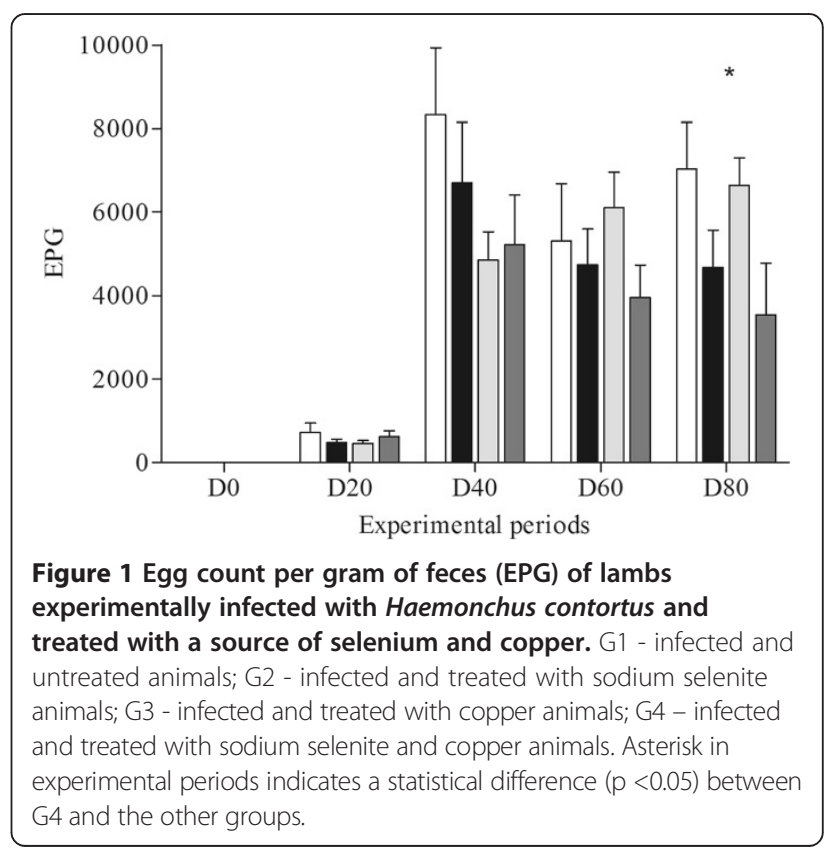


lambs, when compared to the control group. The profiles of the other blood proteins analyzed in the present study (albumin, alpha globulin and beta globulin) did not differ significantly between the groups.

Further studies are needed to better understand how $\mathrm{Se}$ and $\mathrm{Cu}$ affect the fecundity of worms and the ability of the host's immune system to reduce the number of infecting worms. The authors of the present study believe that $\mathrm{Cu}$ and Se supplementation improved the protein profile of sheep and consequently improved both the resistance and resilience of the host against $H$. contortus.

Studies have shown that selenium supplementation provides greater antioxidant protection against the oxidative stress generated by the experimental infection of lambs with $H$. contortus, improving the host immunity $[21,31]$, and that Se supplementation alters the gene expression profiles associated with innate immunity in whole-blood neutrophils of sheep [32].

Copper is an essential trace element which has an important role in many physiological functions, including humoral or cellular immune responses. A copper deficiency has been associated with impaired macrophage respiratory burst capacity and lower prostaglandin and leukotriene formation, causing a greater risk of infections [33]. Copper supplementation promoted an increase in serum globulin levels in lambs, possibly due to an increase in gamma globulin, which tends to improve the immune response to parasites [28].

Based on the data of the present study, there was an improvement in the weight gain of infected lambs that were treated with copper (G3 and G4) when compared with G1 and G2. This result is similar to that reported in a previous study, in which sheep supplemented with copper exhibited an increased feed conversion rate when compared to untreated groups [28].

All groups exhibited an EPG value of zero on D0, with an increase $(\mathrm{p}<0.05)$ only occurring from D20 onwards (Figure 1). This fact validates the method of experimental infection with $H$. contortus used in the present study, since similar results were obtained in studies that established the infection using different methodologies $[34,35]$. After D20, a significant reduction $(\mathrm{p}<0.05)$ was observed in the EPG of the lambs from G4, when compared to the other groups, as well as in the parasite burden recorded at the end of the experiment.

\section{Conclusions}

Selenium and cooper supplementation increased $(\mathrm{P}<0.05)$ the total protein and gamma globulin concentrations and decreased $(\mathrm{P}<0.05)$ the EPG and worm burden. Thus, this injectable supplementation could be used as an auxiliary method to control $H$. contortus in sheep. However, further studies are needed to assess its applicability and economic benefits.

\section{Competing interests}

The authors declare that there are no conflicts of interest.

\section{Authors' contributions}

GCF, FLP, MMC, STAL and RTF participated in the execution of the experiment and the laboratory analysis. MBM, AHHM, JBTR and MLRL performed data analysis and wrote the manuscript. All authors read and approved the final version of the manuscript.

\section{Acknowledgements}

$\mathrm{AHH}$ Minervino is grateful to National Council for Scientific and Technological Development - CNPq, Brazil, for his post-doctoral fellowship (grant \# 500672/2013-0).

\section{Author details}

'Laboratório de Endocrinologia e Metabologia Animal, Departamento de Clínica de Grandes Animais, Hospital Veterinário Universitário, Universidade Federal de Santa Maria (UFSM), Avenida Roraima 1000, CEP 97105-900 Santa Maria, Rio Grande do Sul, Brasil. 'Laboratório de Analises Clínicas Veterinária, Departamento de Clínica de Pequenos Animais, Hospital veterinário Universitário, UFSM, Santa Maria, Brasil. ${ }^{3}$ Laboratório de Doenças Parasitárias da Universidade Federal do Paraná, Rua dos Funcionários, 1540, CEP 80035-050 Curitiba, Paraná, Brasil. `Universidade Federal do Oeste do Pará, (ORCID 0000-0002-6742-3652), Rua Vera Paz, s/n, CEP 68100-000 Santarém, Pará, Brasil. " Laboratório de Bioquímica Toxicologica, Departamento de Ciências da Saúde, UFSM, Santa Maria, Brasil.

Received: 15 January 2014 Accepted: 2 July 2014

Published: 5 August 2014

\section{References}

1. Várady M, Papadopoulos E, Dolinská M, Königová A: Anthelmintic resistance in parasites of small ruminants: sheep versus goats. Helminthologia 2011, 48(3):137-144.

2. Roeber F, Jex AR, Gasser RB: Impact of gastrointestinal parasitic nematodes of sheep, and the role of advanced molecular tools for exploring epidemiology and drug resistance - an Australian perspective. Parasites Vectors 2013, 6:153.

3. Sutherland IA, Shaw J, Shaw RJ: The production costs of anthelmintic resistance in sheep managed within a monthly preventive drench program. Vet Parasitol 2010, 171(3-4):300-304.

4. Miller CM, Waghorn TS, Leathwick DM, Candy PM, Oliver AMB, Watson TG: The production cost of anthelmintic resistance in lambs. Vet Parasitol 2012, 186(3-4):376-381.

5. Amarante AFT, Bricarello PA, Rocha RA, Gennari SM: Resistance of Santa Ines, Suffolk and lle de France sheep to naturally acquired gastrointestinal nematode infections. Vet Parasitol 2004, 120(1-2):91-106.

6. Ortolani EL, Leal MLR, Minervino AHH, Aires AR, Coop RL, Jackson F, Suttle NF: Effects of parasitism on cellular immune response in sheep experimentally infected with Haemonchus contortus. Vet Parasitol 2013, 196(1-2):230-234.

7. Bordoloi G, Jas R, Ghosh JD: Changes in the haemato-biochemical pattern due to experimentally induced haemonchosis in Sahabadi sheep. J Parasit Dis 2012, 36(1):101-105.

8. Kaplan RM, Vidyashankar AN: An inconvenient truth: global warming and anthelmintic resistance. Vet Parasitol 2012, 186(1-2):70-78.

9. Areskog M, Sollenberg S, Engstrõm A, Samson-Himmelstjerna GV, Höglund $\mathrm{J}$ : A controlled study on gastrointestinal nematodes from two Swedish cattle farms showing field evidence of ivermectin resistance. Parasites Vectors 2014, 7:13.

10. Knox MR, Torres-Acosta JFJ, Aguilar-Caballero AJ: Exploiting the effect of dietary supplementation of small ruminants on resilience and resistance against gastrointestinal nematodes. Vet Parasito/ 2006, 139(4):385-393.

11. Nnadi PA, Kamalu TN, Onah DN: The effect of dietary protein supplementation on the pathophysiology of Haemonchus contortus infection in West African Dwarf goats. Vet Parasitol 2007, 148(3-4):256-261

12. Hefnawy AEG, Tórtora-Pérez JL: The importance of selenium and the effects of its deficiency in animal health. Small Ruminant Res 2010, 89(2-3):185-192. 
13. Soli F, Terrill TH, Shaik SA, Getz WR, Miller JE, Vanguru M, Burke JM: Efficacy of copper oxide wire particles against gastrointestinal nematodes in sheep and goats. Vet Parasitol 2010, 168(1-2):93-96.

14. Knox MR: Effectiveness of copper oxide wire particles for Haemonchus contortus control in sheep. Aust Vet J 2002, 80(4):224-227.

15. Burke JM, Miller JE, Olcott DD, Olcott BM, Terrill TH: Effect of copper oxide wire particles dosage and feed supplement level on Haemonchus contortus infection in lambs. Vet Parasitol 2004, 123(3-4):235-243.

16. Burke JM, Miller JE: Evaluation of multiple low doses of copper oxide wire particles compared with levamisole for control of Haemonchus contortus in lambs. Vet Parasitol 2006, 139(1-3):145-149.

17. Waller PJ, Bernes G, Rudby-Martin L, Ljungstrom BL, Rydzik A: Evaluation of copper supplementation to control Haemonchus contortus infections of sheep in Sweden. Acta Vet Scand 2004, 45(3-4):149-160.

18. Burke JM, Miller JE: Dietary copper sulfate for control of gastrointestinal nematodes in goats. Vet Parasitol 2008, 154(3-4):289-293.

19. Yeung KJA, Smith A, Zhao A, Madden KB, Elfrey J, Sullivan C, Levander O, Urban JF, Shea-Donohue T: Impact of vitamin E or selenium deficiency on nematode-induced alterations in murine intestinal function. Exp Parasitol 2005, 109(4):201-208.

20. Van Wyk JA, Cabaret J, Michael LM: Morphological identification of nematode larvae of small ruminants and cattle simplified. Vet Parasitol 2004, 119(4):277-306.

21. Leal MLR, de Camargo EV, Ross DH, Molento MB, Lopes ST, da Rocha JB: Effect of selenium and vitamin $E$ on oxidative stress in lambs experimentally infected with Haemonchus contortus. Vet Res Com 2010, 34(6):549-555.

22. Ramírez-Bribiesca JE, Tórtora JL, Huerta M, Hernández LM, López R, Crosby MM: Effect of selenium-vitamin $\mathrm{E}$ injection in selenium-deficient dairy goats and kids on the Mexican plateau. Arq Bras Med Vet Zootec 2005, 57(1):77-84

23. Eisler R: Eisler's encyclopedia of environmentally hazardous priority chemicals. Amsterdam: Elsevier; 2007.

24. Leal MLR, Benesi FJ, Lisbôa JAN, Coelho CS, Mirandola RMS: Proteinograma sérico de bezerras sadias, da raça holandesa, no primeiro mês pós-nascimento. Braz J vet Res anim Sci 2003, 40:138-145.

25. Coles GC, Jackson F, Pomroy WE, Prichard RK, von Samson-Himmelstjerna G, Silvestre A, Taylor MA, Vercruysse J: The detection of anthelmintic resistance in nematodes of veterinary importance. Vet Parasitol 2006, 136(3-4):167-185.

26. Ueno $\mathrm{H}$, Gonçalves PC: Manual para Diagnóstico das Helmintoses de Ruminantes. Japan International Cooperation Agency-JICA; 1998

27. Kumar N, Garg A, Mudgal V, Dass R, Chaturvedi V, Varshney V: Effect of different levels of selenium supplementation on growth rate, nutrient utilization, blood metabolic profile, and immune response in lambs. Biol Trace Elem Res 2008, 126(1):44-56.

28. Dezfoulian AH, Aliarabi H, Tabatabaei MM, Zamani P, Alipour D, Bahari A, Fadayifar A: Influence of different levels and sources of copper supplementation on performance, some blood parameters, nutrient digestibility and mineral balance in lambs. Livest Sci 2012, 147(1-3):9-19.

29. Arthur JR, McKenzie RC, Beckett GJ: Selenium in the immune system. J Nutr 2003, 133(5):1457S-1459S.

30. Fadayifar A, Aliarabi H, Tabatabaei MM, Zamani P, Bahari A, Malecki M, Dezfoulian AH: Improvement in lamb performance on barley based diet supplemented with zinc. Livest Sci 2012, 144(3):285-289.

31. McCarthy SM, Davis CD: Prooxidant diet provides protection during murine infection with Toxoplasma gondii. J Parasitol 2003, 89(5):886-894.

32. Hugejiletu H, Bobe G, Vorachek WR, Gorman ME, Mosher WD, Pirelli GJ, Hall $J A$ : Selenium supplementation alters gene expression profiles associated with innate immunity in whole-blood neutrophils of sheep. Biol Trace Elem Res 2013, 154(1):28-44.

33. Cerone S, Sansinanea A, Streitenberger S, Garcia C, Auza N: Bovine monocyte-derived macrophage function in induced copper deficiency. Gen Physiol Biophys 2000, 19(1):49-58.
34. Chiejina SN, Behnke JM, Musongong GA, Nnadi PA, Ngongeh LA: Resistance and resilience of West African Dwarf goats of the Nigerian savanna zone exposed to experimental escalating primary and challenge infections with Haemonchus contortus. Vet Parasitol 2010, 171(1-2):81-90.

35. Bambou JC, Archimède H, Arquet R, Mahieu M, Alexandre G, GonzálezGarcia E, Mandonnet N: Effect of dietary supplementation on resistance to experimental infection with Haemonchus contortus in Creole kids. Vet Parasitol 2011, 178(3-4):279-285.

doi:10.1186/1756-3305-7-355

Cite this article as: Fausto et al:: Protein profile of lambs experimentally infected with Haemonchus contortus and supplemented with selenium and copper. Parasites \& Vectors 2014 7:355

\section{Submit your next manuscript to BioMed Central and take full advantage of:}

- Convenient online submission

- Thorough peer review

- No space constraints or color figure charges

- Immediate publication on acceptance

- Inclusion in PubMed, CAS, Scopus and Google Scholar

- Research which is freely available for redistribution

Submit your manuscript at www.biomedcentral.com/submit
C Biomed Central 